\title{
Solvent effects on the structure-property relationship of anticonvulsant hydantoin derivatives: A solvatochromic analysis
}

\author{
Nemanja Trišović, Nataša Valentić and Gordana Ušćumlić
}

\begin{abstract}
Considering the pharmaceutical importance of hydantoins, a set of 25 derivatives of phenytoin, nirvanol and 5methyl-5-phenylhydantoin, the lipophilicities of which were gradually increased by the introduction of different alkyl, cycloalkyl and alkenyl groups in position N3, was synthesized. Their properties under consideration were either estimated empirically, by UVNis spectroscopy, or calculated using established medicinal chemistry software. The UV absorption spectra of the investigated compounds were recorded in the region from 200 to $400 \mathrm{~nm}$, in selected solvents of different polarities. The effects of solvent dipolarity/polarizability and solvent-solute hydrogen bonding interactions were analyzed by means of the linear solvation energy relationship (LSER) concept proposed by Kamlet and Taft. Furthermore, the relationships between solvent-solute interactions and selected structural features of the solutes, which are believed to markedly affect the processes of absorption, distribution, metabolism, excretion and toxicity (ADMETox), were discussed. Satisfactory correlations were found between hydrogen bonding properties and solute size and the in silico calculated bioactivity descriptors, in particular \%Abs. (human intestinal absorption), $\log B B$ (blood-brain barrier permeation) and $\log k_{\mathrm{A}}$ (protein binding affinities) parameters. In view of the results of this study, the investigated hydantoin derivatives met the pharmacokinetic criteria for pre-selection as drug candidates and qualified them for the pharmacodynamic phase of antiepileptic drug development.
\end{abstract}

\section{Background}

Derivatives of hydantoin (imidazolidine-2,4-dione) have been demonstrated to exert various effects on nervous systems, most of which are compatible with an anticonvulsant action. Phenytoin (5,5-diphenylhydantoin, Dilan$\operatorname{tin}^{(B)}$ ) is one of the oldest non-sedative antiepileptic drugs, which is employed in cases of generalized tonicclonic seizures (so-called grand mal epilepsy) and focal motor seizures [1]. Mephenytoin (3-methyl-5-ethyl-5phenylhydantoin, Mesantoin ${ }^{\circledR}$ ) has the same spectrum of indications as phenytoin, but its use is limited to the cases unable to tolerate other drugs [2]. Thus, the demethylated metabolite, nirvanol (5-ethyl-5-phenylhydantoin), was the first hydantoin derivative introduced for the treatment of chorea [3]. Due to numerous side effects, its use was soon abandoned. Ethotoin (3-ethyl-5phenylhydantoin, Peganone ${ }^{\circledR}$ ) has a lower anticonvulsant

\footnotetext{
* Correspondence: naca@tmf.bg.ac.rs

Department of Organic Chemistry, Faculty of Technology and Metallurgy, University of Belgrade, Karnegijeva 4, 11000 Belgrade, Serbia
}

potency than phenytoin and additional hypnotic effects, which limit its clinical use [4].

The anticonvulsant action of hydantoin derivatives is due to the selective block of high-frequency neuronal activity $[5,6]$. The molecular mechanism for this is their binding to the voltage-sensitive sodium channels responsible for the action potential. Phenytoin is suggested to form an array of molecules stacked on a $\beta$ turn segment of the proteic part of the putative receptor site, through the formation of hydrogen bonds with the carbonyl group in position 2 and the $\mathrm{NH}$ group in position 3 [7]. However, this site on the voltage-sensitive sodium channel is still not completely defined. Compounds with increased selectivity for it may provide significant activity and fewer side effects. Regarding the structural demands, Poupaert et al. [8] observed that the anticonvulsant activity was decreased when the hydrogen bond formation ability of the phenytoin molecule was reduced by altering the hydantoin ring into succinimide and pyrrolidinone and when these rings were $\mathrm{N}$ methylated. This study was expanded by Cortes et al. 
[9], who observed loss of activity on changing the hydantoin ring to imidazolone or imidazolidinone, by modifying the hydrogen bonding groups. On the other hand, Roszak and Weaver [10] summarized that the hydantoin ring structure can be split into two fragments, one responsible for the anticonvulsant activity (N3-C4 $(=\mathrm{O})-\mathrm{C} 5)$ and the other for mutagenic effects $(-\mathrm{C} 2(=\mathrm{O})-$ $\mathrm{N} 3(\mathrm{H})$ ). A proper structural modification can enable the differentiation of efficacy from side effects. In general, SAR studies of anticonvulsants revealed the need for the retention of at least one hydrophobic site and hydrogen bond donors/acceptors, in certain relative orientations, for activity to be exhibited.

The first parameter in analyzing the biological activity of a compound is lipophilicity. Lipophilicity governs the transport in vivo and through membranes. It may also influence the formation of a complex between a compound and a receptor or a biomacromolecule at the site of action. Lipophilic interactions were used for an explanation of the binding of hydantoin derivatives to receptors or receptor parts [11]. Lipophilicity is often quantitatively characterized as $\log P$ (the logarithm of the ratio of the concentrations of a solute in a saturated $n$-octanol-water system). Due to the complexity of solvent effects, this property reflects well intermolecular interactions in condensed media. In this context, Abraham proposed a well-accepted solvation equation (1), which quantitatively interprets the relative importance of various properties of solutes in $n$-octanol-water partitioning [12-14]:

$$
\begin{aligned}
& \log P=0.088+0.562 E-1.054 S-0.032 A-3.460 B+3.814 V \\
& (\mathrm{R}=0.9974, \mathrm{sd}=0.116, \mathrm{~F}=23161.6, \mathrm{n}=613)
\end{aligned}
$$

where $E$ is the excess molar refraction, $S$ is the dipolarity/polarizability, $A$ is the overall hydrogen bonding acidity, $B$ is the overall hydrogen bonding basicity, $V$ is the McGowan characteristic molar volume. Evidently, solute dipolarity/polarizability and, especially, solute hydrogen bond basicity favor water, while solute size favors $n$-octanol. This implies that water is more dipolar and is a stronger hydrogen bond acid than $n$-octanol. The minor contribution of the solute hydrogen bond basicity to the partitioning reflects a small difference in the hydrogen bond acidities between these two solvents.

In a recent paper [15], reversed-phase TLC and HPLC retention data were used in correlation studies with molecular descriptors of the pharmacokinetic properties of anticonvulsant succinimide derivatives. The aim of the present study was to apply the solvatochromic comparison method to quantify and correlate multiple solvent effects on the transport properties and interactions of various hydantoins having potential for pharmacological application. A set of twenty five derivatives of phenytoin, nirvanol and 5-methyl-5-phenylhydantoin, the lipophilicities of which were gradually increased by the introduction of alkyl, cycloalkyl and alkenyl substituents at the N3 position (Figure 1), was synthesized. Their UV absorption spectra were recorded in the region 200-400 $\mathrm{nm}$ in fifteen solvents of different polarities. To obtain an insight into the various modes of solvation determining the absorption energies, the effects of solvent dipolarity/polarizability (nonspecific solvent-solute interactions) and hydrogen bonding (specific solventsolute interactions) on the absorption spectra were interpreted by means of a linear solvation energy relationship (LSER) using the Kamlet-Taft Equation of the form:

$$
v=v_{0}+s \pi^{*}+b \beta+a \alpha
$$

where $\pi^{*}$ is an index of the solvent dipolarity/polarizability; $\beta$ is a measure of the solvent hydrogen bonding acceptor (HBA) basicity; $\alpha$ is a measure of the solvent hydrogen bonding donor (HBD) acidity and $v_{0}$ is the regression value of this solvent property in cyclohexane as reference solvent [16]. The regression coefficients $s, b$ and $a$ in Eq. (2) measure the relative susceptibilities of the absorption frequencies to the indicated solvent parameters. This treatment of solvation effects assumes attractive solute-solvent interactions and enables the ability of the investigated compounds to interact with surrounding media to be estimated. Due to this, Eq. (2) served for deriving data for the further QSPR studies.

In previous papers, a set of eight 3-substituted-5,5diphenylhydantoins [17] and a set of nine phenytoin-like

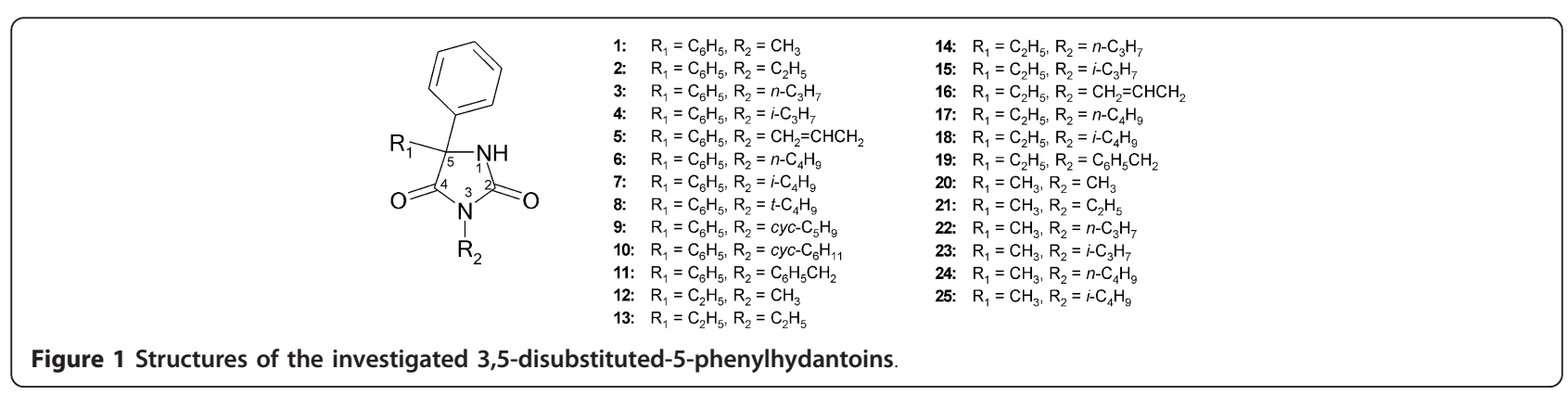


anticonvulsant drugs [18] were assembled to analyze the structural determinants governing the partitioning of the solute between $n$-octanol and water. It was demonstrated that $\log P$ correlates well with the ratio of the contributions of specific solvent-solute interactions in the former case, and with the ratio of the relative contributions of specific and nonspecific interactions in the latter. Here, the same methodology was applied to establish the relationships between solvent-solute interactions, determined empirically, and the ADMETox end points of a larger number of the hydantoin derivatives, obtained by established computational medicinal chemistry methods.

\section{Experimental}

\section{Synthesis of 3,5-disubstituted-5-phenylhydantoins}

5,5-Diphenylhydantoin was commercially obtained (Fluka), while 5-ethyl-5-phenylhydantoin and 5-methyl5 -phenylhydantoin were synthesized by a modification of the method of Bucherer and Lieb [19]. The appropriate ketone was heated with $\left(\mathrm{NH}_{4}\right)_{2} \mathrm{CO}_{3}$ and $\mathrm{KCN}$ in
$50 \%$ ethanol (Figure 2a). The obtained compounds were alkylated at the N3 position using the corresponding alkyl halide in $\mathrm{K}_{2} \mathrm{CO}_{3} / \mathrm{N}, \mathrm{N}$-dimethylformamide to obtain compounds 1-7 and 11-25 (Figure 2b) [20]. When the reaction with alkyl halogenide did not occur due to a change in the reaction pathway or gave a low yield, the derivatives (8-10) were obtained by the Biltz reaction from benzil, respectively urea, and $\mathrm{KOH}$ in ethanol (Figure 2c) [21]. The chemical structures and the purities of the synthesized 3,5-disubstituted-5phenylhydantoins were confirmed by their melting points, and FT-IR, ${ }^{1} \mathrm{H}$ and ${ }^{13} \mathrm{C}$ NMR spectra [Additional file 1].

\section{Spectrometric measurements}

The ${ }^{1} \mathrm{H}$ and ${ }^{13} \mathrm{C}$ NMR spectral measurements were performed on a Bruker AC 250 spectrometer at $200 \mathrm{MHz}$ for the ${ }^{1} \mathrm{H}$ NMR and $50 \mathrm{MHz}$ for the ${ }^{13} \mathrm{C}$ NMR spectra or on a Bruker 300 spectrometer at $300 \mathrm{MHz}$ for the ${ }^{1} \mathrm{H}$ NMR and $75 \mathrm{MHz}$ for the ${ }^{13} \mathrm{C}$ NMR spectra. The<smiles>[R]C1(c2ccccc2)NC(=O)NC1=O</smiles>

$$
\mathrm{R}_{1}=\mathrm{C}_{2} \mathrm{H}_{5}, \mathrm{CH}_{3}
$$

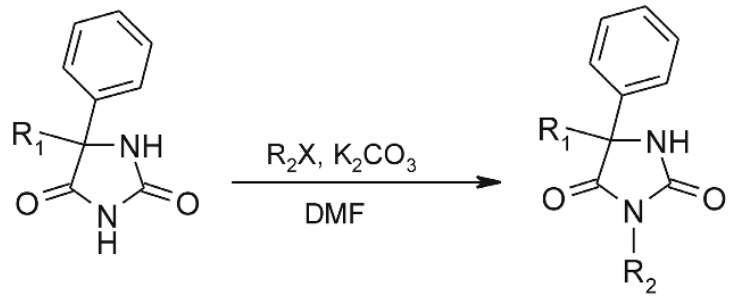
$\mathrm{R}_{1}=\mathrm{C}_{6} \mathrm{H}_{5}, \mathrm{C}_{2} \mathrm{H}_{5}, \mathrm{CH}_{3}$ $\mathrm{R}_{2}=\mathrm{CH}_{3}, \mathrm{C}_{2} \mathrm{H}_{5}, n-\mathrm{C}_{3} \mathrm{H}_{7}, i-\mathrm{C}_{3} \mathrm{H}_{7}, \mathrm{CH}_{2}=\mathrm{CHCH}_{2}, n-\mathrm{C}_{4} \mathrm{H}_{9}, i-\mathrm{C}_{4} \mathrm{H}_{9}, \mathrm{C}_{6} \mathrm{H}_{5} \mathrm{CH}_{2}$

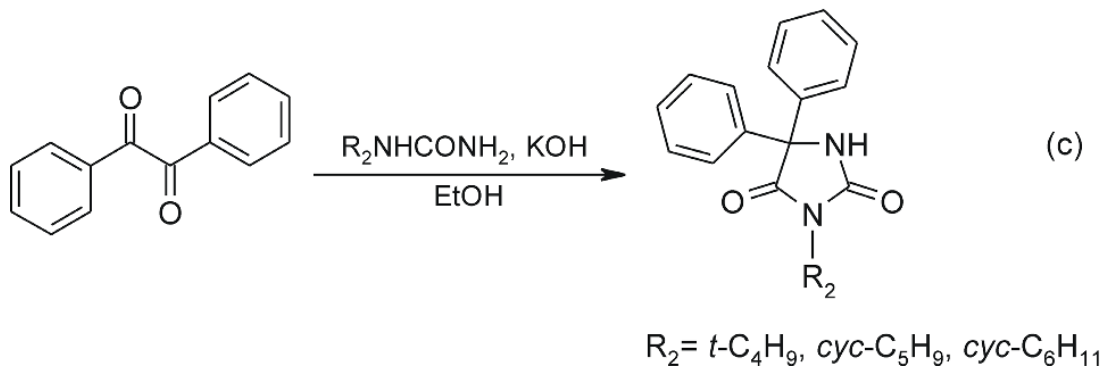

Figure 2 Preparation of the investigated 3,5-disubstituted-5-phenylhydantoins.

(a)

(c) 
spectra were recorded at room temperature in DMSO$d_{6}$. The chemical shifts are expressed in ppm values referred to TMS $\left(\delta_{\mathrm{H}}=0 \mathrm{ppm}\right)$ in the ${ }^{1} \mathrm{H}$ NMR spectra, and the residual solvent signal $\left(\delta_{\mathrm{C}}=39.5 \mathrm{ppm}\right)$ in ${ }^{13} \mathrm{C}$ NMR spectra.

The FT-IR spectra were recorded on a Bomem MB 100 spectrophotometer.

The UV absorption spectra were measured with a Shimadzu 1700 spectrophotometer. The UV spectra were taken in spectro quality solvents (Fluka) at a fixed concentration of $10^{-5} \mathrm{~mol} / \mathrm{L}$. All solvents were of the highest available grade and spectral purities and used without further purification The reported values of $v_{\max }$ are average from three measurements of the corresponding $\lambda_{\max }$. As expected, no significant differences between repeated measurements were observed and their uncertanity was considered to be negligible When broad bands appear (e.g., c, e and $\mathrm{f}$ in Figure 3), high order polynomial curves $(n=9)$ were fitted to the data by using Origin 8 and the absorption maxima were determined on the basis of the first derivative of the fitted curves.

\section{Method of Calculation}

The correlation analysis was realized using Microsoft Office Excel 2003, which considers the 95\% confidence level. The goodness of fit is discussed using the

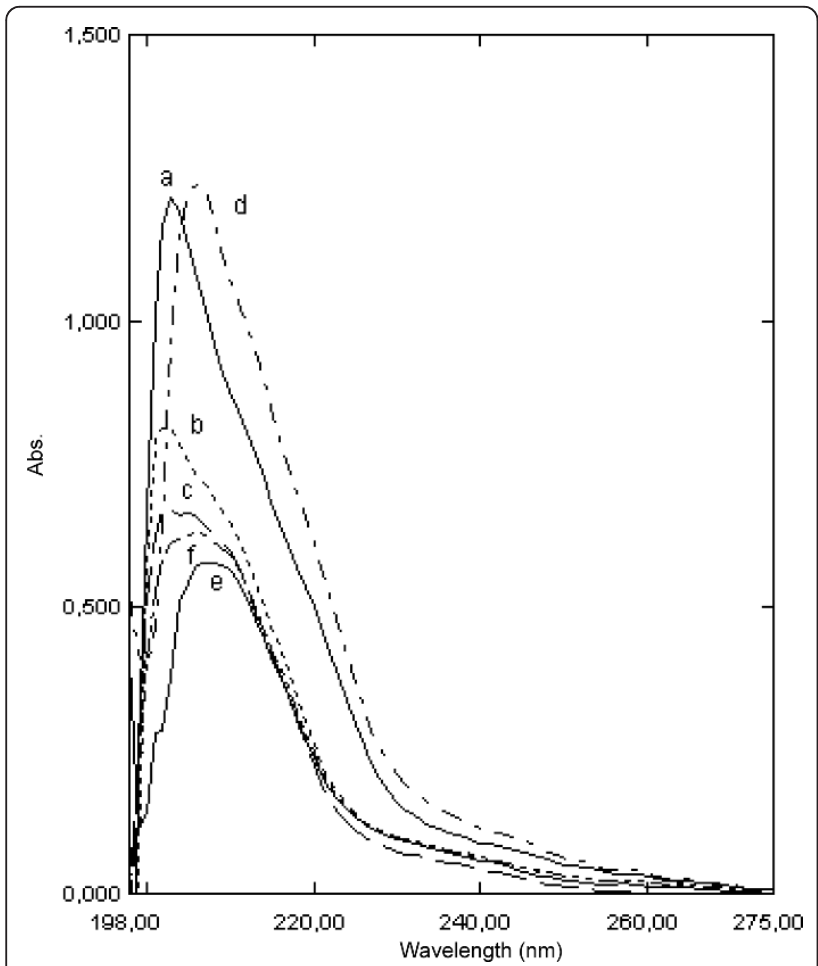

Figure 3 The UV spectra of compounds 1 (a), 13 (b) and 20 (c) in methanol and 1 (d), 13 (e) and 20 (f) in 2-methyl propan-2-ol. correlation coefficient $(R)$, standard deviation $(s d)$ and Fisher's criterion $(F)$.

In the absence of the appropriate experimental data in the literature, computer methods are used do predict ADMETox-related properties of investigated compounds. Their lipophilicities were estimated by calculation of $\log P$ values with the Advanced Chemistry Development (ACD) Software Solaris v. 4.67. The human intestinal absorption (\%Abs.) and the percentage plasma protein data $\left(f_{\mathrm{b}}\right)$ are obtained by the ChemSilico program (http://chemsilico.com).

The corresponding physicochemical parameters and the activity data of the studied compounds are collected in Table 1.

Table 1 Physicochemical properties and pharmacokinetic data of the studied compounds

\begin{tabular}{|c|c|c|c|c|c|c|c|c|c|}
\hline o. & $R_{1}$ & $R_{2}$ & $g$ & $\begin{array}{c}\% \\
\text { Abs. }^{b}\end{array}$ & $\begin{array}{l}\log \\
B B^{b}\end{array}$ & $\begin{array}{l}f_{\mathrm{B}}{ }^{b} \\
(\%)\end{array}$ & $\begin{array}{l}\log \\
k_{\mathrm{A}}{ }^{c}\end{array}$ & $E_{\mathrm{s}}{ }^{\mathrm{d}}$ & $\Sigma \sigma^{* e}$ \\
\hline & $\mathrm{C}_{6} \mathrm{H}_{5}$ & & & 952 & 3 & 26 & 50 & -2 & \\
\hline & $\mathrm{C}_{6} \mathrm{H}_{5}$ & & & & & 33 & 80 & -2.62 & \\
\hline & $\mathrm{C}_{6} \mathrm{H}_{5}$ & $n-C_{3} H_{7}$ & & 0.9 & 0 & 5.173 & 4.515 & -2.91 & 0.48 \\
\hline & $\mathrm{C}_{6} \mathrm{H}_{5}$ & $i-\mathrm{C}_{3} \mathrm{H}_{7}$ & & 5.0 & & 0.15 & 182 & -3.02 & \\
\hline & $\mathrm{C}_{6} \mathrm{H}_{5}$ & $\mathrm{CH}_{2}=$ & & & & 255 & 96 & -2.94 & \\
\hline & ${ }_{6} \mathrm{H}_{5}$ & & & & & & 40 & -2.94 & \\
\hline & $\mathrm{C}_{6} \mathrm{H}_{5}$ & $i-\mathrm{C}_{4} \mathrm{H}_{9}$ & 14 & .1 & 03 & 16 & 4.619 & -3.48 & 0 \\
\hline & $\mathrm{C}_{6} \mathrm{H}_{5}$ & $t-\mathrm{C}_{4} \mathrm{H}_{9}$ & & 96.2 & & 275 & 4.632 & -4.09 & \\
\hline & $\mathrm{C}_{6} \mathrm{H}_{5}$ & & & & & & & -3.06 & \\
\hline & & & & & & & & & \\
\hline 1 & $\mathrm{C}_{6} \mathrm{H}_{5}$ & $\mathrm{C}_{6} \mathrm{H}$ & 89 & 96.4 & & & & & \\
\hline 2 & $\mathrm{C}_{2} \mathrm{H}_{5}$ & $\mathrm{CH}_{3}$ & & & & & & -0.07 & $-c$ \\
\hline 3 & $\mathrm{C}_{2} \mathrm{H}_{5}$ & C t & & & & & 3.340 & -0.14 & -0 \\
\hline 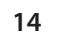 & & & & & & & & & \\
\hline 5 & $\mathrm{C}_{2} \mathrm{H}_{5}$ & $i-C_{3}$ & & & & & & & \\
\hline 6 & $\mathrm{C}_{2} \mathrm{H}_{5}$ & $\mathrm{CH}_{2}=$ & & 46 & 9 & 6 & 3497 & -0.46 & 0 \\
\hline 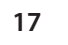 & ${ }_{2} \mathrm{H}_{5}$ & & & & & & 8 & 6 & \\
\hline 8 & $\mathrm{C}_{2} \mathrm{H}_{5}$ & & & & & & & -1.00 & \\
\hline 9 & $\mathrm{C}_{2} \mathrm{H}_{5}$ & $\mathrm{C}_{6} \mathrm{H}_{5} \mathrm{Cl}$ & & & & & & -0.45 & \\
\hline 20 & $\mathrm{CH}_{3}$ & & $3 /$ & 2 & 0.20 & 95.044 & 4.503 & 0.00 & 0.00 \\
\hline 21 & $\mathrm{CH}_{3}$ & & 10 & 93.3 & -0.21 & 01 & 2.926 & -0.07 & -0.10 \\
\hline 22 & $\mathrm{CH}_{3}$ & & 1.93 & 94.3 & -0.2 & 45.258 & 3.137 & -0.36 & -0.12 \\
\hline 23 & $\mathrm{CH}_{3}$ & & .75 & 94.3 & -0.19 & 57.868 & 3.358 & -0.47 & -0.19 \\
\hline 24 & $\mathrm{CH}_{3}$ & & & & & 70.494 & 3.598 & -0.39 & -0.13 \\
\hline 5 & $\mathrm{CH}_{3}$ & $i-\mathrm{C}_{4} \mathrm{H}_{9}$ & 2.28 & 94.8 & -0.16 & 65.26 & 3.494 & -0.93 & -0.13 \\
\hline
\end{tabular}

${ }^{a}$ calculated by ACD Solaris v. 4.67 .

${ }^{b}$ human intestinal absorption data (\%Abs.), the blood-brain permeation $(\log B B)$ and percentage plasma protein binding $\left(f_{\mathrm{b}}\right)$ were calculated by ChemSilico.

cprotein binding affinities were obtained using Eq. 6.

${ }^{d}$ sum of the values of the Taft steric parameters of $R_{1}$ and $R_{2}$.

${ }^{e}$ sum of the values of the Taft electronic parameters of $R_{1}$ and $R_{2}$. 


\section{Results and Discussion}

The absorption spectra of all molecules were characterized by one band with a weak low-energy shoulder appearing in some cases (Figure 3). This is typical for 5phenylhydantoin derivatives. In our previous paper [22], the photophysical facet of the UV absorption of 5-substituted-5-phenylhydantoins was discussed on the basis of the observed and the $a b$ initio calculated absorption spectra in various solvents. The fundamental study of this chromophoric system indicated that the main absorption can be considered to result mainly from an intramolecular charge transfer corresponding to a migration of electron density from the hydantoin moiety to the phenyl ring. The absorbance frequencies of the investigated compounds in fifteen solvents are collected in Table 2. As was expected, the absorbance maxima shifted in solvents of different polarities.

Solvent dipolarity/polarizability and hydrogen bonding are the principal factors in controlling pathways of energy dissipation following the electronic excitation. Their individual contributions are quantified by means of the LSER concept using Eq. (2). The solvent parameters are shown in the Table $3[16,23]$. The correlation of the spectroscopic data was carried out in terms of multiple linear regressions. On the basis of high values of the multiple correlation coefficients and the Fisher criterion, the correlation results of the absorption frequencies of studied molecules in the selected solvent set with the $\pi^{*}, \beta$ and $\alpha$ parameters can be considered as satisfactory. The regression values $v_{\mathrm{o}}, s, b$ and $a$ fit at the $95 \%$ confidence level are presented together with the corresponding standard errors in Table 4. The general effectiveness of the quantification and interpretation of solvent effects on the shifts of the absorption maxima of the investigated molecules is presented in Figure 4 by means of a plot of $v_{\text {exp }}$ versus $v_{\text {calc }}(R=0.989)$. It can be seen that the Kamlet-Taft equation describes better the experimental data for HBA solvents than for HBD solvents. The largest, but still acceptable discrepancies were obtained for aliphatic alcohols with bulky alkyl groups (butan-1-ol, butan-2-ol, 2-methyl propan-2-ol). This might be ascribed to steric interactions which the Kamlet-Taft equation does not take into account. The similar situations were reported in the literature $[24,25]$. However, this was afterwards overcome by inclusion of the Taft steric parameter in the analysis of structural effects on ADMETox properties of the molecules investigated in this work.

The red shift of the absorption bands with increasing solvent dipolarity/polarizability $(s<0)$ indicates a higher dipol moment of the excited state compared with the ground state. This behaviour is in fact typical for intramolecular charge transfer processes. The hydantoin moiety plays the determining role in the specific solvent-solute interactions. The absorption maxima underwent a hypsochromic shift with increasing solvent HBD capacity $(a>0)$. This results from hydrogen bond formation of protic solvents with the oxygene lone pairs of the hydantoin carbonyl groups, making their excitation more difficult. Thus, this implies the stabilization of the ground state relative to the excited state. In contrast, the HBA properties of the solvents, represented by the $b$ coefficient, have a smaller effect. Hydantoins are weak acids dissociating at the imidic $\mathrm{NH}$ group in position 3 , because this allows a more efficient delocalization of the negative charge than ionization at N1. The evidence for the very weak acidic character of the latter position comes from the fact that 3-substituted hydantoins demonstrate no appreciable ionization [26], but the introduction of an electron-withdrawing group at position $\mathrm{C} 5$ increases the acidity of the $\mathrm{N} 1$ hydrogen, making it measurable [27]. Hence, the electron release due to hydrogen bonding of the NH group with HBA solvents lower the energy of the excited state causing the absorption maxima to shift to the red $(b<0)$. Therefore, the stabilization of the excited state relative to the ground state occurs.

Since the $\pi^{*}, \alpha$ and $\beta$ parameters are roughly normalized to cover a range from 0 to 1 [16], it is accepted that the $a / b, a / s$ and $b / s$ ratios provide a convenient measures of the relative contributions of the indicated types of solvent-solute interactions to the absorption maxima shift [28]. As can be seen from Table 5 (the corresponding propagated errors are included), the solvatochromic properties of the investigated compounds result mostly from specific solute-solvent interactions rather than from nonspecific ones. These results are in accordance with their preferred existence as the imido tautomer in solution.

Based on the estimated abilities of the compounds to interact with their environment, the relationship between specific interactions and the selected structural properties, which are related to ADMETox parameters, were investigated. Regioselective protection of the hydantoin ring is important for the optimal sodium channel binding. Smithies suggested that the strong hydrophobic shield produced by the phenyl groups of the phenytoin molecule protects the hydrogen bonds, formed by the imidic part of the hydantoin ring and a $\beta$-bend protein segment from water extrusion [7]. Due to this, further parameters concerned with the solute size are additionally required for an adequate description of the structural features of molecules in such homologous series.

The lipophilicities of the investigated hydantoins were estimated by calculation of $\log P$ values with Advanced Chemistry Development (ACD) Software Solaris v. 4.67 (Table 1). The $\log P$ value is a solvational characteristic, 
Table 2 UV absorption frequencies of the investigated compounds in fifteen solvents

\section{Solvent $\quad v_{\max } \times 10^{-3}\left(\mathrm{~cm}^{-1}\right)$}

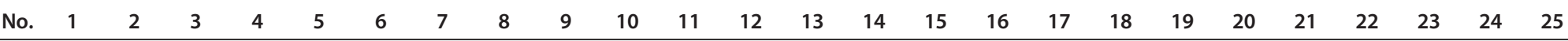

\begin{tabular}{llllllllllllllllllllllllllllll}
\hline Methanol & 48.26 & 47.79 & 47.35 & 48.12 & 47.53 & 46.95 & 47.21 & 47.43 & 47.76 & 47.46 & 47.3 & 48.06 & 47.66 & 47.89 & 47.76 & 47.48 & 48.03 & 48.08 & 47.55 & 47.3 & 47.09 & 46.73 & 46.32 & 46.04 & 46.32
\end{tabular} \begin{tabular}{lllllllllllllllllllllllllll}
\hline Ethanol & 48.54 & 48.03 & 47.34 & 48.36 & 47.64 & 46.9 & 47.25 & 47.44 & 47.94 & 47.48 & 47.13 & 48.23 & 47.76 & 47.94 & 47.81 & 47.61 & 48.03 & 48.17 & 47.62 & 48.31 & 48.21 & 48.08 & 47.89 & 47.76 & 47.94
\end{tabular} \begin{tabular}{llllllllllllllllllllllllllll}
\hline Propan-1-ol & 48.36 & 47.57 & 46.94 & 48.17 & 47.39 & 46.38 & 46.82 & 47.35 & 47.39 & 47.3 & 46.91 & 47.85 & 47.37 & 47.76 & 47.52 & 47.17 & 47.8 & 47,89 & 47.26 & 48.08 & 48.03 & 48.01 & 47.94 & 47.89 & 47.94 \\
\hline
\end{tabular} \begin{tabular}{lllllllllllllllllllllllllllll}
\hline Propan-2-ol & 48.36 & 47.88 & 47.57 & 48.15 & 47.78 & 47.24 & 47.47 & 47.63 & 47.76 & 47.67 & 47.39 & 48.12 & 47.83 & 47.97 & 47.91 & 47.76 & 48.05 & 48.08 & 47.8 & 48.17 & 48.08 & 48.03 & 47.92 & 47.88 & 47.94
\end{tabular} \begin{tabular}{llllllllllllllllllllllllll}
\hline Butan-1-ol & 46.82 & 46.55 & 46.2 & 46.82 & 46.24 & 45.7 & 45.96 & 46.3 & 46.43 & 46.28 & 46.01 & 47.57 & 47.25 & 47.44 & 47.35 & 47.07 & 47.52 & 47.53 & 47.08 & 47.85 & 47.8 & 47.76 & 47.62 & 47.55 & 47.62 \\
\hline Butan-2-ol & 147.49 & 47.3 & 47.09 & 47.43 & 47.17 & 46.92 & 47.04 & 47.14 & 46.98 & 47.23 & 47.17 & 47.63 & 47.52 & 47.54 & 47.52 & 47.44 & 47.58 & 47.6 & 47.44 & 47.95 & 47.93 & 47.9 & 47.85 & 47.81 & 47.85
\end{tabular} \begin{tabular}{llllllllllllllllllllllllllll}
\hline Butan-2-ol & 47.49 & 47.3 & 47.09 & 47.43 & 47.17 & 46.92 & 47.04 & 47.14 & 46.98 & 47.23 & 47.17 & 47.63 & 47.52 & 47.54 & 47.52 & 47.44 & 47.58 & 47.6 & 47.44 & 47.95 & 47.93 & 47.9 & 47.85 & 47.81 & 47.85
\end{tabular}

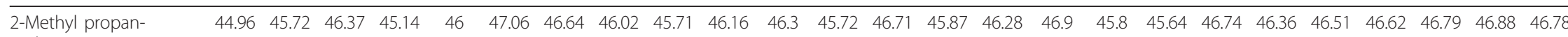
2-ol

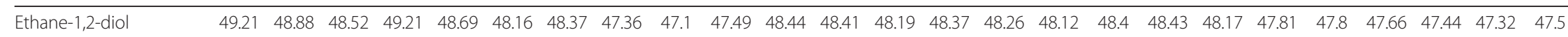

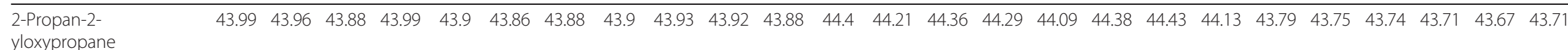
yloxypropane

$$
\text { Oxolane }
$$
$\begin{array}{llllllllllllllllllllllllll}41.41 & 41.23 & 41.04 & 41.34 & 41.13 & 40.92 & 41.01 & 41.06 & 41.03 & 41.16 & 41.09 & 41.88 & 41.49 & 41.81 & 41.65 & 41.35 & 41.85 & 41.92 & 41.45 & 41.22 & 41.17 & 41.14 & 41.06 & 41 & 41.08\end{array}$

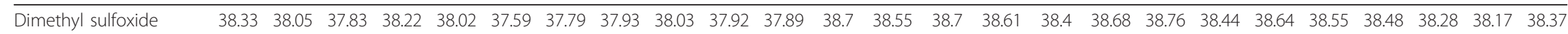
\begin{tabular}{lllllllllllllllllllllllllll}
\hline Methyl acetate & 42.12 & 41.85 & 41.57 & 42.05 & 41.7 & 41.36 & 41.51 & 41.47 & 41.58 & 41.5 & 41.58 & 42.45 & 41.91 & 42.35 & 42.13 & 41.73 & 42.41 & 42.51 & 41.86 & 41.67 & 41.62 & 41.56 & 41.42 & 41.34 & 41.45 \\
\hline
\end{tabular} \begin{tabular}{llllllllllllllllllllllllllll}
\hline Ethyl acetate & 42.2 & 41.98 & 41.73 & 42.14 & 41.84 & 41.56 & 41.68 & 41.68 & 41.79 & 41.71 & 41.74 & 42.59 & 42.1 & 42.5 & 42.3 & 41.94 & 42.56 & 42.65 & 42.06 & 41.86 & 41.81 & 41.77 & 41.66 & 41.58 & 41.68 \\
\hline
\end{tabular}

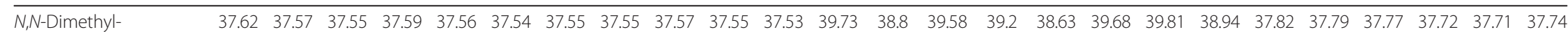
formamid

Non-Dimethy-

acetamide 
Table 3 Solvent parameters

\begin{tabular}{lccc}
\hline Solvent & $\boldsymbol{\pi}^{*}$ & $\boldsymbol{\beta}$ & $\boldsymbol{\alpha}$ \\
\hline Methanol & 0.60 & 0.62 & 0.93 \\
Ethanol & 0.54 & 0.77 & 0.83 \\
Propan-1-ol & 0.52 & 0.83 & 0.78 \\
Propan-2-ol & 0.48 & 0.95 & 0.76 \\
Butan-1-ol & 0.47 & 0.88 & 0.79 \\
Butan-2-ol & 0.40 & 0.80 & 0.69 \\
2-Methyl propan-2-ol & 0.41 & 1.01 & 0.68 \\
Ethane-1,2-diol & 0.92 & 0.52 & 0.90 \\
2-Propan-2-yloxypropane & 0.27 & 0.49 & 0 \\
Oxolane & 0.58 & 0.55 & 0 \\
Dimethyl sulfoxide & 1.00 & 0.76 & 0 \\
Methyl acetate & 0.60 & 0.42 & 0 \\
Ethyl acetate & 0.55 & 0.45 & 0 \\
N,N-Dimethyl- -formamide & 0.88 & 0.69 & 0 \\
N,N-Dimethyl- -acetamide & 0.88 & 0.76 & 0 \\
\hline
\end{tabular}

since it is directly related to the change in the Gibbs energy of solvation of a solute between $n$-octanol and water. The calculated values of $\log P$ were plotted against the regression coefficient $a$ from Eq. (2), as a measure of the importance of a solute to accept a hydrogen bond, revealing two linear relationships (Figure 5), mainly due to the different structural characteristics of the substituent $R_{1}$.

A satisfactory correlation of $\log P$ with $a$ is achieved through the additional inclusion of the sum of the Taft $E_{\mathrm{s}}$ values of the substituents $\mathrm{R}_{1}$ and $\mathrm{R}_{2}$ [29], which is presented by Eq. (3).

$$
\begin{aligned}
& \log P=9.12( \pm 1.65)-0.82( \pm 0.18) a / 1000-0.48( \pm 0.06) \Sigma E_{s} \\
& (R=0.903, s d=0.38, F=42.2, n=22)
\end{aligned}
$$

Compounds 8, 19 and 24 are outliers from Eq. (3) for statistical reasons, but they have no significant effect on the modeling made for the investigated set of compounds. The obtained correlation corresponds well to the Abraham characterization of the $n$-octanol-water partitioning system [12]. As was stated, water is a stronger hydrogen bond acid than $n$-octanol and hydrogen bond basic solutes interact weakly with the latter solvent. Solute size leads to an increase in $\log P$, as expected, due to the larger energy required to create a bigger cavity in water and the greater dispersion force interactions with solutes in $n$-octanol.

\begin{tabular}{|c|c|c|c|c|c|c|c|c|c|}
\hline No. & $\mathrm{R}_{1}$ & $\mathrm{R}_{2}$ & $v_{0} \times 10^{-3}\left(\mathrm{~cm}^{-1}\right)$ & $s \times 10^{-3}\left(\mathrm{~cm}^{-1}\right)$ & $b \times 10^{-3}\left(\mathrm{~cm}^{-1}\right)$ & $a \times 10^{-3}\left(\mathrm{~cm}^{-1}\right)$ & $R^{a}$ & $F^{b}$ & $s d^{c}$ \\
\hline 1 & $\mathrm{C}_{6} \mathrm{H}_{5}$ & $\mathrm{CH}_{3}$ & $48.07( \pm 0.94)$ & $-5.49( \pm 1.13)$ & $-6.34( \pm 0.96)$ & $9.68( \pm 0.62)$ & 0.980 & 107.4 & 0.89 \\
\hline 2 & $\mathrm{C}_{6} \mathrm{H}_{5}$ & $\mathrm{C}_{2} \mathrm{H}_{5}$ & $47.82( \pm 1.18)$ & $-5.92( \pm 1.09)$ & $-5.74( \pm 1.42)$ & $9.33( \pm 0.64)$ & 0.983 & 103.3 & 0.85 \\
\hline 3 & $\mathrm{C}_{6} \mathrm{H}_{5}$ & $n-C_{3} H_{7}$ & $47.44( \pm 1.21)$ & $-6.26( \pm 1.12)$ & $-5.04( \pm 1.45)$ & $8.95( \pm 0.66)$ & 0.981 & 94.5 & 0.87 \\
\hline 4 & $\mathrm{C}_{6} \mathrm{H}_{5}$ & $i-\mathrm{C}_{3} \mathrm{H}_{7}$ & $48.08( \pm 1.28)$ & $-5.60( \pm 1.18)$ & $-6.34( \pm 1.53)$ & $9.66( \pm 0.70)$ & 0.980 & 90.7 & 0.92 \\
\hline 5 & $\mathrm{C}_{6} \mathrm{H}_{5}$ & $\mathrm{CH}_{2} \mathrm{CH}=\mathrm{CH}$ & $47.57( \pm 1.22)$ & $-6.04( \pm 1.13)$ & $-5.34( \pm 1.49)$ & $9.12( \pm 0.67)$ & 0.981 & 93.7 & 0.88 \\
\hline 6 & $\mathrm{C}_{6} \mathrm{H}_{5}$ & $n-\mathrm{C}_{4} \mathrm{H}_{9}$ & $47.20( \pm 1.36)$ & $-6.63( \pm 1.26)$ & $-4.44( \pm 1.64)$ & $8.57( \pm 0.75)$ & 0.975 & 71.7 & 0.98 \\
\hline 7 & $\mathrm{C}_{6} \mathrm{H}_{5}$ & $i-\mathrm{C}_{4} \mathrm{H}_{9}$ & $47.34( \pm 1.26)$ & $-6.38( \pm 1.16)$ & $-4.77( \pm 1.51)$ & $8.80( \pm 0.69)$ & 0.979 & 86.3 & 0.90 \\
\hline 8 & $\mathrm{C}_{6} \mathrm{H}_{5}$ & $t-\mathrm{C}_{4} \mathrm{H}_{9}$ & $47.34( \pm 0.99)$ & $-6.87( \pm 0.92)$ & $-4.18( \pm 1.19)$ & $8.54( \pm 0.54)$ & 0.987 & 138.7 & 0.71 \\
\hline 9 & $\mathrm{C}_{6} \mathrm{H}_{5}$ & cyc- $-\mathrm{C}_{5} \mathrm{H}_{9}$ & $47.50( \pm 0.93)$ & $-6.89( \pm 0.86)$ & $-4.25( \pm 1.12)$ & $8.54( \pm 0.51)$ & 0.989 & 156.7 & 0.69 \\
\hline 10 & $\mathrm{C}_{6} \mathrm{H}_{5}$ & cyc- $\mathrm{C}_{6} \mathrm{H}_{11}$ & $47.34( \pm 1.00)$ & $-6.81( \pm 0.93)$ & $-4.18( \pm 1.20)$ & $8.55( \pm 0.55)$ & 0.987 & 135.2 & 0.72 \\
\hline 11 & $\mathrm{C}_{6} \mathrm{H}_{5}$ & $\mathrm{C}_{6} \mathrm{H}_{5} \mathrm{CH}_{2}$ & $47.52( \pm 1.22)$ & $-6.25( \pm 1.13)$ & $-5.21( \pm 1.47)$ & $8.87( \pm 0.67)$ & 0.980 & 90.4 & 0.88 \\
\hline 12 & $\mathrm{C}_{2} \mathrm{H}_{5}$ & $\mathrm{CH}_{3}$ & $48.33( \pm 1.08)$ & $-6.09( \pm 1.00)$ & $-5.31( \pm 1.29)$ & $8.67( \pm 0.59)$ & 0.984 & 110.9 & 0.77 \\
\hline 13 & $\mathrm{C}_{2} \mathrm{H}_{5}$ & $\mathrm{C}_{2} \mathrm{H}_{5}$ & $47.56( \pm 1.02)$ & $-6.47( \pm 0.95)$ & $-4.21( \pm 1.23)$ & $8.59( \pm 0.56)$ & 0.986 & 127.8 & 0.73 \\
\hline 14 & $\mathrm{C}_{2} \mathrm{H}_{5}$ & $n-\mathrm{C}_{3} \mathrm{H}_{7}$ & $48.16( \pm 1.06)$ & $-6.09( \pm 0.98)$ & $-5.12( \pm 1.27)$ & $8.57( \pm 0.58)$ & 0.984 & 113.1 & 0.76 \\
\hline 15 & $\mathrm{C}_{2} \mathrm{H}_{5}$ & $i-\mathrm{C}_{3} \mathrm{H}_{7}$ & $47.85( \pm 1.02)$ & $-6.29( \pm 0.94)$ & $-4.65( \pm 1.22)$ & $8.55( \pm 0.56)$ & 0.986 & 124.6 & 0.73 \\
\hline 16 & $\mathrm{C}_{2} \mathrm{H}_{5}$ & $\mathrm{CH}_{2} \mathrm{CH}=\mathrm{CH}$ & $47.29( \pm 1.05)$ & $-6.51( \pm 0.98)$ & $-3.93( \pm 1.27)$ & $8.55( \pm 0.58)$ & 0.985 & 120.7 & 0.76 \\
\hline 17 & $\mathrm{C}_{2} \mathrm{H}_{5}$ & $n-C_{4} H_{9}$ & $48.27( \pm 1.05)$ & $-6.08( \pm 0.97)$ & $-5.26( \pm 1.27)$ & $8.63( \pm 0.58)$ & 0.984 & 114.5 & 0.76 \\
\hline 18 & $\mathrm{C}_{2} \mathrm{H}_{5}$ & $i-\mathrm{C}_{4} \mathrm{H}_{9}$ & $48.40( \pm 1.09)$ & $-6.01( \pm 1.01)$ & $-5.44( \pm 1.31)$ & $8.63( \pm 0.59)$ & 0.983 & 107.0 & 0.78 \\
\hline 19 & $\mathrm{C}_{2} \mathrm{H}_{5}$ & $\mathrm{C}_{6} \mathrm{H}_{5} \mathrm{CH}_{2}$ & $47.42( \pm 1.04)$ & $-6.38( \pm 0.96)$ & $-4.13( \pm 1.25)$ & $8.51( \pm 0.57)$ & 0.985 & 121.6 & 0.75 \\
\hline 20 & $\mathrm{CH}_{3}$ & $\mathrm{CH}_{3}$ & $47.52( \pm 0.75)$ & $-6.55( \pm 0.70)$ & $-4.54( \pm 0.91)$ & $9.69( \pm 0.41)$ & 0.993 & 288.3 & 0.51 \\
\hline 21 & $\mathrm{CH}_{3}$ & $\mathrm{C}_{2} \mathrm{H}_{5}$ & $47.45( \pm 0.71)$ & $-6.60( \pm 0.66)$ & $-4.45( \pm 0.86)$ & $9.68( \pm 0.39)$ & 0.994 & 322.0 & 0.51 \\
\hline 22 & $\mathrm{CH}_{3}$ & $n-\mathrm{C}_{3} \mathrm{H}_{7}$ & $47.35( \pm 0.69)$ & $-6.72( \pm 0.64)$ & $-4.21( \pm 0.83)$ & $9.57( \pm 0.38)$ & 0.995 & 339.4 & 0.50 \\
\hline 23 & $\mathrm{CH}_{3}$ & $i-\mathrm{C}_{3} \mathrm{H}_{7}$ & $47.23( \pm 0.66)$ & $-6.95( \pm 0.61)$ & $-3.89( \pm 0.79)$ & $9.43( \pm 0.36)$ & 0.995 & 377.0 & 0.47 \\
\hline 24 & $\mathrm{CH}_{3}$ & $n-C_{4} H_{9}$ & $47.12( \pm 0.64)$ & $-7.05( \pm 0.59)$ & $-3.69( \pm 0.77)$ & $9.36( \pm 0.35)$ & 0.995 & 395.4 & 0.46 \\
\hline 25 & $\mathrm{CH}_{3}$ & $i-\mathrm{C}_{4} \mathrm{H}_{9}$ & $47.23( \pm 0.63)$ & $-6.86( \pm 0.63)$ & $-3.95( \pm 0.81)$ & $9.46( \pm 0.37)$ & 0.995 & 354.1 & 0.49 \\
\hline
\end{tabular}

Table 4 Regression fits to the solvatochromic parameters

${ }^{a}$ Correlation coefficient

${ }^{\mathrm{b}}$ Standard deviation

${ }^{\mathrm{c}}$ Fisher test 


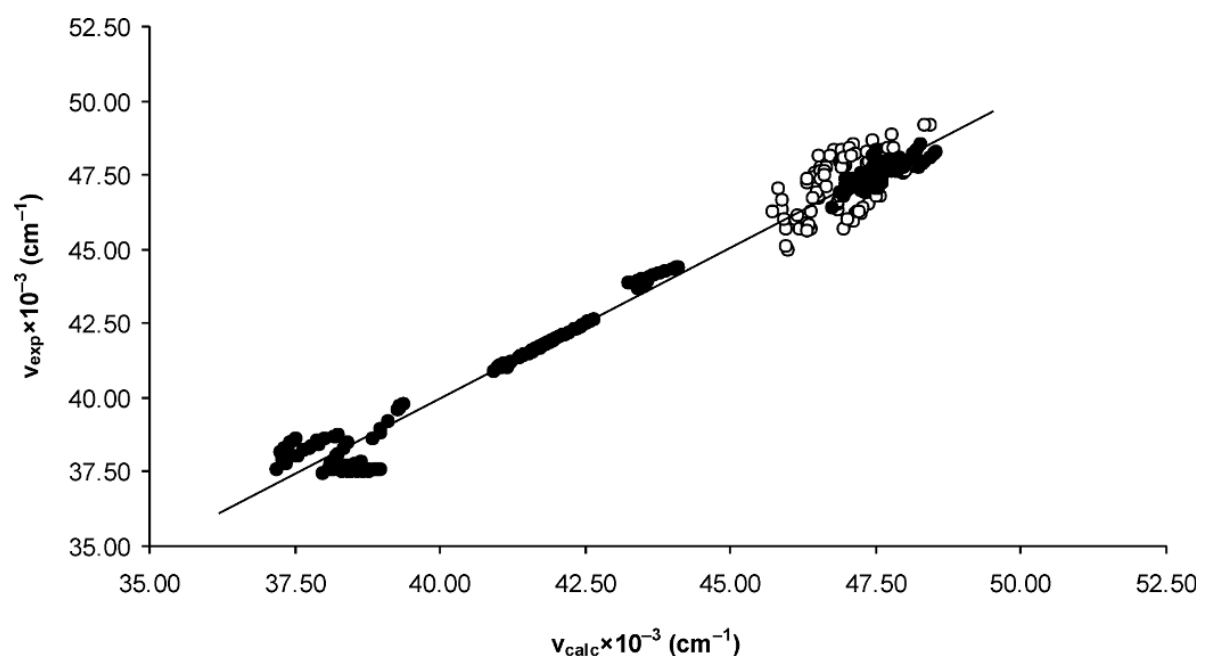

Figure $4 \mathrm{~A}$ comparison between the experimental $\left(v_{\text {exp }}\right)$ and the calculated absorption frequencies ( $\left.v_{\text {calc }}\right)$. The open points present data for the following alcohols: butan-1-ol, butan-2-ol and 2-methyl propan-2-ol.

Different relationships have been established between $\log P$ and absorption or permeability in intestinal models [30,31], blood-brain barrier models [32] and cell-culture models $[33,34]$, to name just a few. Here, the $a$ coefficient from Eq. (2) was used to model the human intestinal absorption (HIA) data of the investigated hydantoin derivatives, obtained with ChemSilico. The HIA values (\%Abs.) are expressed as the percentage of a compound absorbed by the intestine (Table 1). 3,5-Disubstituted-5-phenylhydantoins, with an HIA greater than $90 \%$, can be classified as well absorbed. A satisfactory correlation of the \%Abs. data with $a$ and $\Sigma E_{\mathrm{s}}$ (Eq. (4)), obtained for 23 compounds, reveals that the hydrogen bond basicity and solute size are important for absorption. A possible reason for the outliers $\mathbf{1 2}$ and $\mathbf{2 0}$ is that some additional factors might contribute to the absorption of the hydantoin derivatives bearing small hydrophobic substituents. In general, this is in agreement with work of Abraham, who suggested that hydrogen bond properties are dominant in governing the $H I A$ $[35,36]$. However, it should be borne in mind that the absorption of the investigated compounds may not only be controlled by the passive diffusion rate, but also by the in vivo dissolution rate in the small intestinal fluid.

$$
\begin{aligned}
& \% A b s .=98.96( \pm 1.59)-0.51( \pm 0.18) a / 1000-0.50( \pm 0.06) \Sigma E_{s} \\
& (R=0.904, s d=0.37, F=45.0, n=23)
\end{aligned}
$$

In the search for drugs targeted at CNS diseases, the ideal candidates must be able to effectively penetrate the blood-brain barrier (BBB). For anticonvulsant assays, the optimal lipophilicity for the penetration through the BBB appears to exist at about $\log P=2[37,38]$. The relative affinities for the blood or brain tissue can be expressed in terms of the blood-brain partition coefficient, $\log B B=\log \left(C_{\text {brain }} / C_{\text {blood }}\right)$, where $C_{\text {brain }}$ and $C_{\text {blood }}$ are the equilibrium concentrations of a drug in the brain and blood, respectively. Based on data from the ChemSilico program, all compounds have a high chance of entering the brain because their $\log B B$ values are greater than -0.3 (Table 1). Modeling of the $\mathrm{BBB}$ penetration has been the subject of many studies [39-41]. Here, the relationship between the brain-blood concentration ratio with $a$ and $\Sigma E_{\mathrm{s}}$ implies that the properties concerned with molecular size and hydrogen bond formation are important contributors to $\log B B$. The outliers removed to obtain Eq. (5) are compounds 10, 11 and 19 bearing a large hydrophobic substituent at position 3. It might be expected that compounds with such a structural feature would fill the hydrophobic region of the receptor and thereafter their activities would decrease due to steric hindrance during the steric interaction of the ligand and receptor.

$$
\begin{aligned}
& \log B B=-0.64( \pm 0.21)+0.05( \pm 0.02) a / 1000-0.07( \pm 0.01) \Sigma E_{s} \\
& (R=0.911, s d=0.05, F=46.2, n=22)
\end{aligned}
$$

As mentioned previously, the therapeutical usefulness of hydantoin-based anticonvulsants is limited owning to their inherent toxicity. Additional evidence for solvation effects on the structure-activity relationship of the investigated compounds was obtained by the correlation of the calculated protein binding affinities $\left(k_{\mathrm{A}}\right)$ values with the $a$ coefficient. It was shown that the toxic effects of phenytoin correlate best with the level of the free drug in plasma [42]. Protein binding values $\left(f_{\mathrm{b}}\right.$, fraction bound) are given as the percentage of the total plasma concentration of a drug that is bound to all plasma proteins (Table 1). Human serum albumin (HSA), the most abundant protein in blood plasma (concentration 0.53- 
Table 5 Relative contribution of the solvatochromic effects

\begin{tabular}{|c|c|c|c|}
\hline No & $a /|b|$ & $a /|s|$ & $b / s$ \\
\hline 1 & $\begin{array}{c}1.53 \\
( \pm 0.25)\end{array}$ & $\begin{array}{c}1.76 \\
( \pm 0.38)\end{array}$ & $\begin{array}{c}1.15 \\
( \pm 0.30)\end{array}$ \\
\hline 2 & $\begin{array}{c}1.63 \\
( \pm 0.42)\end{array}$ & $\begin{array}{c}1.58 \\
( \pm 0.31)\end{array}$ & $\begin{array}{c}0.97 \\
( \pm 0.30)\end{array}$ \\
\hline 3 & $\begin{array}{c}1.78 \\
( \pm 0.53)\end{array}$ & $\begin{array}{c}1.43 \\
( \pm 0.28)\end{array}$ & $\begin{array}{c}0.81 \\
( \pm 0.27)\end{array}$ \\
\hline 4 & $\begin{array}{c}1.52 \\
( \pm 0.38)\end{array}$ & $\begin{array}{c}1.73 \\
( \pm 0.38)\end{array}$ & $\begin{array}{c}1.13 \\
( \pm 0.36)\end{array}$ \\
\hline 5 & $\begin{array}{c}1.71 \\
( \pm 0.49)\end{array}$ & $\begin{array}{c}1.51 \\
( \pm 0.30)\end{array}$ & $\begin{array}{c}0.88 \\
( \pm 0.30)\end{array}$ \\
\hline 6 & $\begin{array}{c}1.93 \\
( \pm 0.73)\end{array}$ & $\begin{array}{c}1.29 \\
( \pm 0.27)\end{array}$ & $\begin{array}{c}0.67 \\
( \pm 0.28)\end{array}$ \\
\hline 7 & $\begin{array}{c}1.84 \\
( \pm 0.60)\end{array}$ & $\begin{array}{c}1.38 \\
( \pm 0.27)\end{array}$ & $\begin{array}{c}0.75 \\
( \pm 0.27)\end{array}$ \\
\hline 8 & $\begin{array}{c}2.04 \\
( \pm 0.60)\end{array}$ & $\begin{array}{c}1.24 \\
( \pm 0.18)\end{array}$ & $\begin{array}{c}0.61 \\
( \pm 0.19)\end{array}$ \\
\hline 9 & $\begin{array}{c}2.01 \\
( \pm 0.54)\end{array}$ & $\begin{array}{c}1.24 \\
( \pm 0.17)\end{array}$ & $\begin{array}{c}0.62 \\
( \pm 0.18)\end{array}$ \\
\hline 10 & $\begin{array}{c}2.05 \\
( \pm 0.60)\end{array}$ & $\begin{array}{c}1.26 \\
( \pm 0.19)\end{array}$ & $\begin{array}{c}0.61 \\
( \pm 0.20)\end{array}$ \\
\hline 11 & $\begin{array}{c}1.70 \\
( \pm 0.50)\end{array}$ & $\begin{array}{c}1.42 \\
( \pm 0.28)\end{array}$ & $\begin{array}{c}0.83 \\
( \pm 0.28)\end{array}$ \\
\hline 12 & $\begin{array}{c}1.63 \\
( \pm 0.41)\end{array}$ & $\begin{array}{c}1.42 \\
( \pm 0.25)\end{array}$ & $\begin{array}{c}0.87 \\
( \pm 0.26)\end{array}$ \\
\hline 13 & $\begin{array}{c}2.04 \\
( \pm 0.61)\end{array}$ & $\begin{array}{c}1.33 \\
( \pm 0.21)\end{array}$ & $\begin{array}{c}0.65 \\
( \pm 0.21)\end{array}$ \\
\hline 14 & $\begin{array}{c}1.67 \\
( \pm 0.43)\end{array}$ & $\begin{array}{c}1.41 \\
( \pm 0.25)\end{array}$ & $\begin{array}{c}0.84 \\
( \pm 0.25)\end{array}$ \\
\hline 15 & $\begin{array}{c}1.84 \\
( \pm 0.50)\end{array}$ & $\begin{array}{c}1.36 \\
( \pm 0.22)\end{array}$ & $\begin{array}{c}0.74 \\
( \pm 0.22)\end{array}$ \\
\hline 16 & $\begin{array}{c}2.18 \\
( \pm 0.72)\end{array}$ & $\begin{array}{c}1.31 \\
( \pm 0.22)\end{array}$ & $\begin{array}{c}0.60 \\
( \pm 0.22)\end{array}$ \\
\hline 17 & $\begin{array}{c}1.64 \\
( \pm 0.41)\end{array}$ & $\begin{array}{c}1.42 \\
( \pm 0.25)\end{array}$ & $\begin{array}{c}0.87 \\
( \pm 0.25)\end{array}$ \\
\hline 18 & $\begin{array}{c}1.59 \\
( \pm 0.40)\end{array}$ & $\begin{array}{c}1.44 \\
( \pm 0.26)\end{array}$ & $\begin{array}{c}0.91 \\
( \pm 0.27)\end{array}$ \\
\hline 19 & $\begin{array}{c}2.06 \\
( \pm 0.64)\end{array}$ & $\begin{array}{c}1.33 \\
( \pm 0.22)\end{array}$ & $\begin{array}{c}0.65 \\
( \pm 0.22)\end{array}$ \\
\hline 20 & $\begin{array}{c}2.13 \\
( \pm 0.44)\end{array}$ & $\begin{array}{c}1.48 \\
( \pm 0.17)\end{array}$ & $\begin{array}{c}0.69 \\
( \pm 0.16)\end{array}$ \\
\hline 21 & $\begin{array}{c}2.18 \\
( \pm 0.43)\end{array}$ & $\begin{array}{c}1.47 \\
( \pm 0.16)\end{array}$ & $\begin{array}{c}0.67 \\
( \pm 0.15)\end{array}$ \\
\hline 22 & $\begin{array}{c}2.27 \\
( \pm 0.46)\end{array}$ & $\begin{array}{c}1.42 \\
( \pm 0.15)\end{array}$ & $\begin{array}{c}0.63 \\
( \pm 0.14)\end{array}$ \\
\hline 23 & $\begin{array}{c}2.42 \\
( \pm 0.50)\end{array}$ & $\begin{array}{c}1.36 \\
( \pm 0.13)\end{array}$ & $\begin{array}{c}0.56 \\
( \pm 0.12)\end{array}$ \\
\hline 24 & $\begin{array}{c}2.54 \\
( \pm 0.54)\end{array}$ & $\begin{array}{c}1.33 \\
( \pm 0.12)\end{array}$ & $\begin{array}{c}0.52 \\
( \pm 0.12)\end{array}$ \\
\hline 25 & $\begin{array}{c}2.39 \\
( \pm 0.50)\end{array}$ & $\begin{array}{c}1.38 \\
( \pm 0.14)\end{array}$ & $\begin{array}{c}0.58 \\
( \pm 0.13)\end{array}$ \\
\hline
\end{tabular}

$0.75 \mathrm{mM}$ ), has multiple hydrophobic binding sites and binds a diverse set of drugs [43]. The percentage data were converted into an equivalent binding affinity $k_{\mathrm{A}}$ with the following formula (Eq. (6)) derived from the law of mass action. $k_{\mathrm{A}}$ is the binding affinity to HSA under the assumption that binding occurs exclusively to HSA, a binary complex is formed and an excess of albumin (concentration $0.6 \mathrm{mmol} / \mathrm{L}$, [HSA]) is present compared to the concentration of the drug [44].

$$
\log k_{\mathrm{A}}=\log \frac{\left[f_{\mathrm{b}}\right]}{1-\left[f_{\mathrm{b}}\right]}-\log [\text { HSA }]
$$

Based on the data from Table 1, the binding of drugs to serum albumin can generally be explained by hydrophobic interactions within such homologous series. However, the correlation between the $\log k_{\mathrm{A}}$ values and $a$, enhanced through the use of $\Sigma \sigma^{*}$ and $\Sigma E_{\mathrm{s}}$ as additional parameters [29] (Eq. (7)), implies that the binding of all the investigated compounds to albumin depends on specific molecular recognition, such as directed hydrogen bonds, charge interactions and space filling of binding pockets.

$$
\begin{aligned}
& \log k_{A}=6.88( \pm 1.05)-0.38( \pm 0.11) a / 1000-0.21( \pm 0.07) \Sigma E_{s}+0.59( \pm 0.29) \Sigma \sigma * \\
& (R=0.920, s d=0.24, F=38.4, n=25)
\end{aligned}
$$

Evidentially, bulky electron-withdrawing substituents attached to the hydantoin ring are needed to achieve a relatively high level of protein binding. As a result of this, derivatives of phenytoin are expected to be the least toxic hydantoin-based anticonvulsants.

\section{Conclusions}

As a preliminary investigation of the interactions of potential anticonvulsant drugs, a set of 25 derivatives of phenytoin, nirvanol and 5-methyl-5-phenylhydantoin, the lipophilicities of which were gradually increased by the introduction of different substituents in position N3, was synthesized. The satisfactory correlation of their UV absorption frequencies with the Kamlet-Taft solvatochromic equation indicated that the selected model interpreted correctly the linear solvation energy relationship for the complex hydantoin system in the employed solvents. The LSER method enabled the overall solvent effects to be quantitatively estimated and separated into specific and nonspecific contributions.

The solvatochromic behavior of the investigated compounds was related to their pharmacologically relevant properties. Accompanying calculations of $\log P$ and various pharmacokinetic data (human intestinal absorption, blood-brain barrier permeation and protein binding affinities) were performed and correlated with the spectroscopically-derived hydrogen bond accepting abilities. The obtained models additionally represented how the electronic and steric effects of substituents attached to the hydantoin ring determine biological partitioning and interactions of the compounds with target sites. Moreover, their good agreement with the regression models of Abraham was demonstrated for the contributions of 


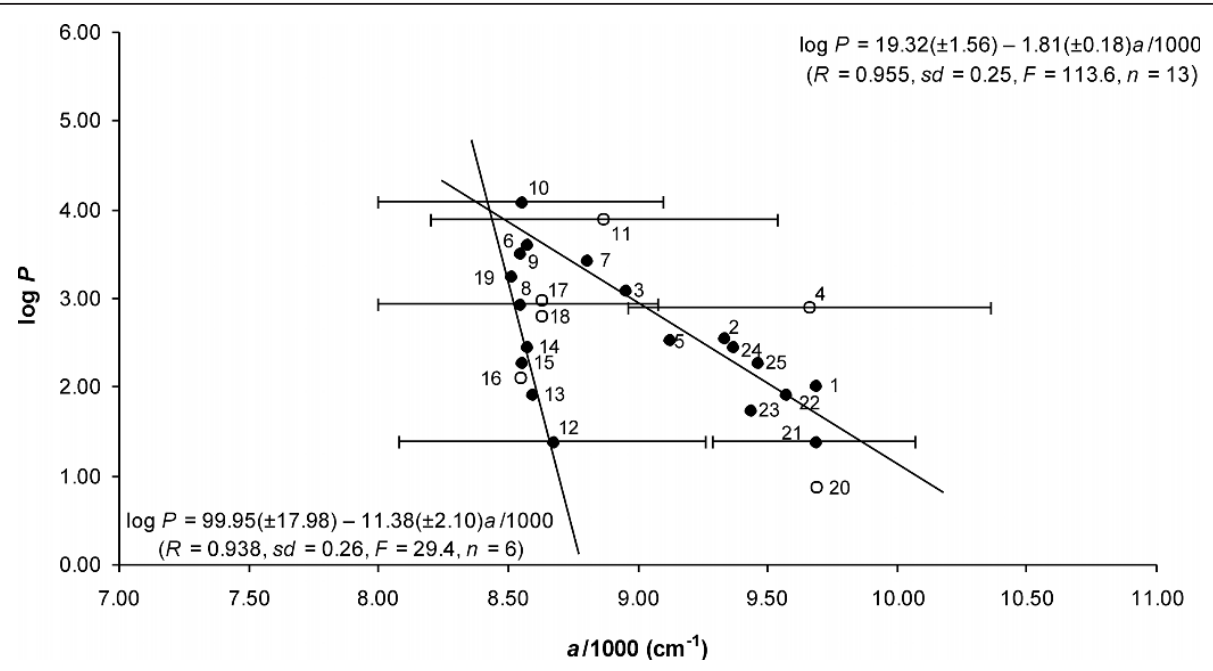

Figure 5 Correlation between the $\log P$ values and the regression coefficient $a$ derived from Eq. (2). The presented error bars correspond to standard errors of $\mathbf{4}, \mathbf{8}, \mathbf{1 0}, \mathbf{1 1}, \mathbf{1 2}$ and $\mathbf{2 1}$ (Table 4).

hydrogen bond basicity and molecular size. The approach proposed in this work could be applied to optimize ADMETox properties of compounds with potential for pharmacological application.

\section{Additional material}

Additional file 1: Experimental details and data of the investigated compounds. Additional file 1 includes the experimental procedures and physico-chemical characterization of the investigated compounds.

\section{Acknowledgements}

This work was performed within the framework of the research project No. ON 172013, supported by the Ministry of Science and Technological Development of the Republic of Serbia.

\section{Authors' contributions}

NT carried out the synthesis and characterization of the compounds. NV performed the calculations of molecular descriptors and the statistical analysis. GU conceived of the study and participated in its design and coordination. All authors read and approved the final manuscript.

\section{Competing interests}

The authors declare that they have no competing interests.

Received: 6 June 2011 Accepted: 14 October 2011

Published: 14 October 2011

\section{References}

1. Yaari $Y$, Selzer ME, Pincus $J H$ : Phenytoin: mechanisms of its anticonvulsant action. Ann Neurol 1986, 20:171-184.

2. Küpfer A, Brilis GM, Watson JT, Harris TM: A major pathway of mephenytoin metabolism in man. Aromatic hydroxylation to $\mathrm{p}$ hydroxymephenytoin. Drug Metab Dispos 1980, 8:1-4.

3. Ellis FA: Reactions to nirvanol, phenytoin sodium and phenobarbital: report of a case of ectodermosis erosiva pluriorificialis following the ingestion of phenytoin sodium. South Med J 1943, 36:575-579.

4. Carter CA, Helms RA, Boehm R: Ethotoin in seizures of childhood and adolescence. Neurol 1984, 34:791-795.
5. Brouillette WJ, Brown GB, DeLorey TM, Liang G: Sodium channel binding and anticonvulsant activities of hydantoins containing conformationally constrained 5-phenyl substituents. J Pharm Sci 1990, 79:871-874.

6. Brown ML, Brown GB, Brouillette WJ: Effects of $\log P$ and phenyl ring conformation on the binding of 5-phenylhydantoins to the voltagedependent sodium channel. J Med Chem 1997, 40:602-607.

7. Smythies JR: Receptor modeling for anticonvulsant and convulsant drugs. In Antiepileptic Drugs: Mechanism of Action. Edited by: Glasser GH, Penry JK, Woodbury DM. New York: Raven Press; 1980:207-222.

8. Poupaert JH, Vandervorst D, Guiot P, Moustafa MMM, Dumont P: Structureactivity relationships of phenytoin-like anticonvulsant drugs. J Med Chem 1984, 27:76-78.

9. Cortes S, Liao ZK, Watson D, Kohn H: Effect of structural modification of the hydantoin ring on anticonvulsant activity. J Med Chem 1985, 28:601-606.

10. Roszak AW, Weaver DF: 5,5-Diphenyl-2-thiohydantoin. Acta Cryst C 1998, 54:1168-1170

11. Scholl S, Koch A, Henning D, Kempter G, Kleinpeter E: The influence of structure and lipophilicity of hydantoin derivatives on anticonvulsant activity. Struct Chem 1999, 10:355-366.

12. Abraham MH, Lieb WR, Franks NP: Role of hydrogen bonding in general anesthesia. J Pharm Sci 1991, 80:719-724.

13. Abraham $\mathrm{MH}$ : Application of solvation equations to chemical and biochemical processes. Pure Appl Chem 1993, 65:2503-2512.

14. Abraham MH, Ibrahim A, Zissimos AM, Zhao YH, Comer J, Reynolds DP: Application of hydrogen bonding calculations in property based drug design. Drug Discov Today 2002, 7:1056-1063.

15. Perišić-Janjić N, Kaliszan R, Wiczling P, Milošević N, Ušćumlić G, Banjac N: Reversed-phase TLC and HPLC retention data in correlation studies with in silico molecular descriptors and druglikeness droperties of newly synthesized anticonvulsant succinimide derivatives. Mol Pharmaceut 2011, 8:555-563.

16. Kamlet MJ, Abboud JLM, Abraham MH, Taft RW: Linear solvation energy relationships. 23. A comprehensive collection of the solvatochromic parameters, $\pi^{*}, a$, and $\beta$, and some methods for simplifying the generalized solvatochromic equation. J Org Chem 1983, 48:2877-2887.

17. Banjac N, Ušćumlić G, Valentić N, Mijin D: Solvent effects on the structureactivity relationship of pharmacological active 3-substituted-5,5diphenylhydantoins. J Solution Chem 2007, 36:869-878.

18. Trišović N, Banjac N, Valentić N, Ušćumlić G: Solvent effects on the structure-activity relationship of phenytoin-like anticonvulsant drugs. J Solution Chem 2009, 38:199-208.

19. Bucherer HT, Lieb VA: Syntheses of hydantoins. II. Formation of substituted hydantoins from aldehydes and ketones. J Prakt Chem 1934, 141:5-43. 
20. Suzuki H, Kneller MB, Rock DA, Jones JP, Trager WF, Rettie AE: Active-site characteristics of CYP2C19 and CYP2C9 probed with hydantoin and barbiturate inhibitors. Arch Biochem Biophys 2004, 429:1-15.

21. Muccioli GG, Poupaert JH, Wouters J, Norberg B, Poppitz W, Scriba GKE, Lambert DM: A rapid and efficient microwave-assisted synthesis of hydantoins and thiohydantoins. Tetrahedron 2003, 59:1301-1307.

22. Trišović N, Valentić N, Erović M, Đaković-Sekulić T, Ušćumlić $G$, Juranić I: Synthesis, structure and solvatochromic properties of pharmacologically active 5-substituted 5-phenylhydantoins. Monats Chem , doi:10.1007/ s00706-011-0639-7..

23. Marcus $Y$ : The properties of organic liquids that are relevant to their use as solvating solvents. Chem Soc Rev 1993, 22:409-416.

24. Mather D, Shorter J: The influence of the solvent on organic reactivity. Part 5. Kinetics of the reaction of diazodiphenylmethane with benzoic acid in branched-chain alkanols and in electronegatively substituted alcohols. J Chem Soc Perkin Trans II 1983, 1179-1183.

25. Bauer M, Rollberg A, Barth A, Spange S: Differentiating between dipolarity and polarizability effects of solvents using the solvatochromism of barbiturate dyes. Eur J Org Chem 2008, 4475-4481.

26. Stuckey RE: The absorption spectra of organic compounds containing nitrogen. I. Derivatives of hydantoin. J Chem Soc 1947, 169:331-334.

27. Tan SF, Ang KP, Fong YF, Jayachandran H: Ionization constants of 5arylmethylenehydantoins in $80 \%(\mathrm{w} / \mathrm{w})$ dimethyl sulfoxide-water at $25^{\circ}$. J Chem Soc Perkin Trans II 1988, 473-476.

28. Reinchard C: Solvents and Solvent Effects in Organic Chemistry Weinheim: Wiley - VCH; 2003, 457.

29. Unger SH, Hansch C: Quantitative models of steric effects. Prog Phys Org Chem 1976, 12:91-118.

30. Komiya I, Park JY, Kamani A, Ho NFH, Higuchi WI: Quantitative mechanistic studies in simultaneous fluid flow and intestinal absorption using steroids as model solutes. Int J Pharm 1980, 4:249-262.

31. Taylor DC, Pownwall R, Burke W: The absorption of $\beta$-adrenoceptor antagonists in rat in-situ small intestine; the effect of lipophilicity. $J$ Pharm Pharmacol 1985, 37:280-283.

32. Levin VA: Relationship of octanol/water partition coefficient and molecular weight to rat brain capillary permeability. J Med Chem 1980, 23:682-684.

33. Artursson P: Epithelial transport of drugs in cell culture. I: A model for studying the passive diffusion of drugs over intestinal absorptive (Caco2) cells. J Pharm Sci 1990, 79:476-482.

34. Buur A, Trier L, Magnusson C, Artursson P: Permeability of 5-fluorouracil and prodrugs in Caco-2 cell monolayers. Int J Pharm 1996, 129:223-231.

35. Zhao YH, Le J, Abraham MH, Hersey A, Eddershaw PJ, Luscombe CN, Boutina D, Beck G, Sherborne B, Cooper I, Platts JA: Evaluation of human intestinal absorption data and subsequent derivation of a quantitative structure-activity relationship (QSAR) with the Abraham descriptors. J Pharm Sci 2001, 90:749-784

36. Zhao YH, Abraham MH, Hersey A, Luscombe CN: Quantitative relationship between rat intestinal absorption and Abraham descriptors. Eur J Med Chem 2003, 38:939-947.

37. Hansch C, Björkroth JP, Leo A: Hydrophobicity and central nervous system agents: on the principle of minimal hydrophobicity in drug design. J Pharm Sci 1987, 76:663-687.

38. Yamagami C, Sonoda C, Takao N, Tanaka M, Yamada J, Horisaka K, Fujita T: A quantitative structure-activity study of anticonvulsant benzyl N,Ndimethylcarbamates. Chem Pharm Bull 1982, 30:4175-4180.

39. Lombardo F, Blake JF, Curatolo WJ: Computation of brain-blood partitioning of organic solutes via free energy calculations. J Med Chem 1996, 39:4750-4755.

40. Hou T, Xu X: ADME evaluation in drug discovery. 1. Applications of genetic algorithms to the prediction of blood-brain partitioning of a large set of drugs. J Mol Model 2002, 8:337-349.

41. Norinder U, Haeberlein M: Computational approaches to the prediction of the blood-brain distribution. Adv Drug Deliv Rev 2002, 54:291-313.

42. Peterson GM, McLean S, Aldous S, von Witt RJ, Mollingen KS: Plasma protein binding of phenytoin in 100 epileptic patients. Brit J Clin Pharmacol 1982, 14:298-300.

43. Seedher N, Agarwal P: Reversible binding of some isoxazolyl penicillins with serum albumin using fluorescence spectroscopic technique. Ind J Pharm Sci 2006, 68:327-331.
44. Kratochwil NA, Huber W, Müller F, Kansy M, Gerber PR: Predicting plasma protein binding of drugs: a new approach. Biochem Pharmacol 2002, 64:1355-1374

doi:10.1186/1752-153X-5-62

Cite this article as: Trišović et al:. Solvent effects on the structureproperty relationship of anticonvulsant hydantoin derivatives: A solvatochromic analysis. Chemistry Central Journal 2011 5:62.

Publish with ChemistryCentral and every
scientist can read your work free of charge
"Open access provides opportunities to our
colleagues in other parts of the globe, by allowing
anyone to view the content free of charge."
W. Jeffery Hurst, The Hershey Company.
- available free of charge to the entire scientific community
- peer reviewed and published immediately upon acceptance
- cited in PubMed and archived on PubMed Central
- yours - you keep the copyright
submit your manuscript here:
http://www.chemistrycentral.com/manuscript/

